\title{
COLLECTIVISM V. INDIVIDUALISM: CAN THE EU LEARN FROM THE HISTORY OF THE ISRAELI KIBBUTZ?'
}

\author{
Nellie Munin \\ LLD, Advocate, independent scholar, Former Minister of Economic Affairs \\ in the Israeli Mission to the EU \\ Former Chief Legal Advisor, State Revenue Administration, \\ the Israeli Ministry of Finance. \\ Former Associate Professor at the law school, \\ Zefat Academic College, Israel.
}

\begin{abstract}
The EU seems to share some basic characteristics with the original model of the Israeli Kibbutz: both aim at enhancing a society based on solidarity and mutual guarantee, where members' contribution is proportional to their abilities while their benefits are determined according to their needs. Both are underlined by the perception of subsidiarity, according to which the alliance is stronger than each of its individual members and can thus enhance their welfare more efficiently. On the other hand, both the Kibbutz and the EU were or are facing similar dilemmas. This paper reviews the efforts of Israeli Kibbutzim to encounter these challenges throughout their history, assessing whether a lesson relevant to current EU dilemmas can be drawn.
\end{abstract}

Keywords: Kibbutz, European Union, Integration, Crises.

\section{INTRODUCTION}

The kibbutz is a unique way of community life, forming one of the symbols of the State of Israel. In Israel, there are 270 kibbutzim, encompassing less than 150,000 inhabitants. ${ }^{2}$

The EU is an international alliance of 28 member states, encompassing more than 500 million inhabitants.

There are some other, substantial differences between the kibbutz and the EU: first, the kibbutz was established bottom up, by groups of pioneers who, at first, were not directed by a supreme authority such as a government. The EU was established top down by a group of leaders and thinkers. The top down approach continues to characterize EU development and functioning, forming a constant source of tension between EU authorities, on the one hand, and its citizens and member states, on the other hand. Second, kibbutz founders aimed to create a new form of community, inspired by communism or socialism. EU founders were motivated by a political desire to prevent the next

1 This article was presented at the Israel 1947-1967: creating the country conference hosted by the Theodor Herzl Fund and the faculty of Social Studies at Masaryk University, Brno, the Czech Republic in 21-23 February 2017. The author would like to thank her daughter Shany Munin for triggering this article by invoking the idea of EU-kibbutz similarities.

2 This number forms about $2 \%$ of the Jewish population, encompassing 6.45 million inhabitants, and about $1.7 \%$ of the entire Israeli population, encompassing 8.63 million inhabitants at the end of 2016. The Israeli Central Bureau of Statistics, 2017 Population. Available at: http://www.cbs.gov.il/publications17/yarhon0117/pdf/b1.pdf 
war and by a capitalist desire to create a strong and competitive economic alliance. Third, the kibbutz started from a collective model, based on full sharing of assets, burden and privileges. The EU started with individual member states, striving towards gradual market integration.

Despite these differences, the EU seems to share some basic characteristics with the original model of the Israeli Kibbutz: both are underlined by the principle of their members' equality; Both aim at enhancing a society based on solidarity and mutual guarantee, where members' contribution is proportional to their abilities while their benefits are determined according to their needs; both follow the notion of subsidiarity, according to which the alliance is stronger than each of its individual members and can thus enhance their welfare more efficiently, e.g. by initiating mutual projects that could not be obtained individually.

Attempting to live by their basic values, both the kibbutz and the EU were or are facing similar dilemmas.

This paper will depict the basic characteristics and perceptions of the kibbutz, reviewing the changing strategies Israeli kibbutzim chose to meet these challenges during the years. Assessing their success or failure, it will try to draw a lesson relevant to current EU dilemmas, taking into account the differences between these two models.

\section{THE ISRAELI KIBBUTZ - 1909-2017}

\section{Brief History of the Kibbutz}

The kibbutz - a unique social and economic unit, traditionally based on agriculture, was developed by Jewish newcomers to Palestine long before the State of Israel was established. The first kibbutz, established in 1909, was Degania, situated in the North of Israel, near the Sea of Galilee. ${ }^{3}$ Kibbutzim's founders faced a tough surrounding: most of the land was either rocky, swampy or a desert. The sanitary conditions were poor. Diseases such as malaria, typhus and cholera were common. Arab and Bedouin threats were constant. The Ottoman authorities, who ruled Palestine until 1918, had made Jewish immigration to Palestine difficult and restricted land purchases by Jews. The British regime that replaced the Ottoman regime following World War I, encouraged Jewish immigration, mainly from eastern Europe and Russia, to Palestine during the 1920's. At that time, Jewish youth movements flourished, being active both in Palestine and abroad, facilitating immigration to Israel and the development of new kibbutzim. Kibbutzim established during this period enjoyed many more members than the first ones. ${ }^{4}$ Most of them were enthusiastic, ideologically motivated youngsters. Some kibbutzim movements were developed, representing different ideological, political and religious orientations. Each kibbutz became associated with one of these movements. ${ }^{5}$ Gradually, the kibbutzim assumed a military role, actively participating in the protection of the 'Yishuv' - the pre-state, and the resistance to the British regime that later begun to restrict Jewish immigration

3 See Degania Group. Available at: www.Degania.org.il.

For example, while Degania started with 12 members, Ein Harod, situated in the North near Mount Gilboa, had 239 members when it moved to its permanent location in 1930.

5 For the different ideological narratives of the different movements see: STERNHELL, Z.: The Founding Myths of Israel: Nationalism, Socialism and the Making of the Jewish State. Princeton: Princeton University Press, 1998. 
and the establishment of new Jewish settlements, due to Arab pressure. ${ }^{6}$ Some kibbutzim were established in outlying areas to ensure that the land would be incorporated into the future Jewish state.

When Israel was established, in 1948, the kibbutz was already a well-developed, leading model of settlement, practiced by $6.5 \%$ of the Jewish population of Israel. ${ }^{7}$

In the coming years, the kibbutzim continued to assume important defense functions. Their relative contribution to the new state's defense, politics and economy was larger than their relative share in its population. ${ }^{8}$ They took an active part in the challenges faced by the new state. Their flourishing and strong position in the Israeli society continued until mid-1980's.

Despite their success, internal social cracks begun to occur and grow in the kibbutzim during these years. A severe financial crisis that took place from end 1970's, reinforcing a social crisis, forced the kibbutzim into a process of privatization that had substantially changed their original nature, from collective to more individual, privatized settlements. Nowadays these 'renewed kibbutzim', encompassing the majority of the 270 kibbutzim existing in Israel, ${ }^{9}$ enjoy a new blossom, attracting many Israelis to choose them as their homes. Some of them present very impressive economic achievements. ${ }^{10}$

\section{The original collectivist model}

The kibbutzim begun as utopian communities, a combination of Zionism and socialism. ${ }^{11}$ Many of the Kibbutzim's founders, originating in Eastern Europe and pre-revolution Russia, were inspired by the socialist vision. Others were educated in youth movements, according to the same principles. They shaped the original kibbutz accordingly.

The original model of the kibbutz was very idealistic, thus very strict. Its original founders, many of whom originated in middle or high class families abroad and deserted their convenient life style out of idealism, were ready to suffer very tough standards of living to avoid any compromise on their model. Thus, for example, members of the original kibbutzim did not enjoy any private ownership: all assets were shared by all members. This rule, illustrating a high level of material equality, applied

LIEBLICH, A.:.Kibbutz Makom. Jerusalem and Tel Aviv. New York: Shocken, 1986, pp. 29-30, 73-85.

While the percentage of kibbutz members compared to other Israeli citizens gradually descended, the number of kibbutz members constantly augmented. In 1948, there were 46,940 kibbutz members in Israel. In 2005, 117,685 kibbutz members formed only 2.2\% of the Israeli Jewish population. The Israeli Central Bureau of Statstics. The Kibbutzim and Their Population: Demographic Changes During the Years 1961-2005, 2008. Available at: http://www.cbs.gov.il/publications/ kib05/pdf/h_print.pdf

8 For example, in the Independence War (1948) Israel lost 5,800 soldiers. 850 (12\%) were kibbutz members. In the Six Day War (1967) Israel lost 800 soldiers. 200 (25\%) of them were kibbutz members; In the 1960's, when kibbutz members formed $4 \%$ of the Israeli population, $15 \%$ of the Israeli parliament (Knesset) members were kibbutz members: BETTELHEIM, B.: The Children of the Dream. New York: Simon \& Schuster, 2001, p. 15. During these years, the kibbutzim's standard of living was higher than that of the rest of Israel. One of the signs for that was the establishment of swimming pools in many kibbutzim.

9 This number has remained fairly stable since the 1970's.

10 One of the richest kibbutzim in Israel is Sasa (a traditional kibbutz), situated in the Galilee, owning 'Plasan', a factory developing and producing special custom-built vehicle armor, exporting $95 \%$ of its production to the US armed forces. Another Northern kibbutz, Hanita (a 'renewed kibbutz' including 175 full members, 55 economically independent members, and about 200 inhabitants) recently sold its firm: 'Hanita coating (Kotlav)', producing engineered polyester films and laminates, to American Avery Dennison for 75 million dollars. ZURIEL HARARI, K.: The Basketball Player, the Lebanese and Kibbutz Elders: Behind the Huge Exit of Hanita. In: Calcalist, 2017. Available at: http://www.calcalist. co.il/local/articles/0,7340,L-3706492,00.html

11 GOLDENBERG, S. - WEKERLE, G.: From utopia to total institution in a single generation: the kibbutz and Bruderhof. In: International Review of Modern Sociology, 1972, vol. 2, no. 2, pp. 224-232. 
to the land, ${ }^{12}$ the machines, the tents, huts and later houses, to the animals and plants. However, it also applied to personal belongings such as clothes, furniture, electric appliances etc. ${ }^{13}$

A hundred years ago, a kibbutznik somewhere wanted to bring a kettle home... He was told he had to drink his tea in the dining room like everyone else. ${ }^{14}$

Any belongings owned by new kibbutz members, or accepted by kibbutz members, were immediately confiscated to the general benefit. Thus, for example, there is documentation of a female kibbutz member who worked in the cowshed wearing an elegant fur coat that was confiscated from another, newly arrived immigrant kibbutz member. ${ }^{15}$ However, such luxuries were rare and in general, all kibbutzim were very poor and their members suffered hunger on daily bases.

Those who had families in Israel, attempting to stay with their families for a while, to rest from the hard work or even to recover sickness, were immediately condemned by the group, perceived as undermining equality. ${ }^{16}$

The value of self-labour was enshrined. It meant that the kibbutz must rely solely on its members to do all the necessary work. The kibbutz would not employ external labour. Each of the members was apt to work for the kibbutz, doing his or her best to meet the demands of the job assigned to them, based on the kibbutz's needs, sometimes irrespective of their education, personal qualifications or aspirations.

Substantial equality was further enhanced by a basic principle, inspired by communism: 'From each according to his/her ability, to each according to his/her need.'

The responsibility to raise the kibbutz children, feed them, and educate them was perceived as collective. They were sleeping in 'children's houses', separate from their families, both to nurture the value of their equal treatment by their educators, and to free their parents from most of their parental responsibilities, to let them dedicate more time to the collective needs of the kibbutz. The family used to meet for short intervals every afternoon and during weekends. ${ }^{17}$

Personal matters such as the desire to get married, to have children or to acquire professional or personal skills or training were subject to a decision of the kibbutz's general assembly, assuming that all such matters had potentially borne financial and social implications for the entire community and thus should be decided by it. ${ }^{18}$

12 The land was state-owned and the kibbutz only leased it. Leasing was originally limited to agricultural use. Nevertheless, in 1992, following a huge wave of immigrants from the former USSR, the Israeli government allowed the kibbutzim, in collaboration with entrepreneurs, to build neighborhoods on this land and sell the apartments built in the free market, for considerable profits, as if they've owned this land. Some kibbutzim, such as Ramat Rachel near Jerusalem, and Glil Yam near Tel Aviv, managed to make huge profits of this venture. These deals drew severe public criticism, on grounds that giving the right to build on state land and gain profits to the kibbutzim discriminates against other Israeli citizens who did not accept such a present ' from the State. Eventually, seven Israeli Court of Justice judges deleted this government decision in consensus, in 2002. BOSSO, N.: When Farmers Found Gold in the Land. In: TheMarker, 2014. Available at: http://www.themarker.com/magazine/1.2456648; HCJ 244/00 The New Discourse Association for Democratic Discourse v. The National Infrastructure Minister, judgement of 29.8.02.

13 LIEBLICH, A.: Kibbutz Makom. Jerusalem and Tel Aviv. New York: Shocken, 1986, pp. 35, 44, 259; INBARI, A.: Habayta. Tel Aviv: Yediot Sfarim, 2009.

14 SHOR, Ze'ev, head of the Kibbutz Movement. In: RIFKIN, L.: Adult Children of the Dream. In: The Jerusalem Post, 2010. Available at: http://www.jpost.com/Jerusalem-Report/Adult-Children-of-the-Dream.

15 LIEBLICH, A.: Kibbutz Makom. Jerusalem and Tel Aviv. New York: Shocken, 1986, p. 91.

16 Ibid., pp. 43, 92.

17 Ibid., pp. 52, 99, 104,109, 111-115.

18 BAR ON, M. - MELTZER, A.: The Kibbutz. Documentary (4 chapters), 2013, chapter 3. Available at: https://www.youtube.com/watch?v=pVbgxd7Z3mQ 
As economic units, all the kibbutzim relied on agriculture. Nevertheless, many of them also developed industries. A minority of kibbutz members were assigned by the kibbutz to work outside the kibbutz, as politicians, army officers, professionals etc. Their remuneration was paid to the kibbutz, rather than to them. The kibbutz could have decided to stop their work outside the kibbutz at any time. Originally, the kibbutz supplied its members food, clothes and shelter. As the economic situation of the kibbutzim improved, their members were also entitled to a small personal 'budget' at the kibbutz's store, or to a small personal allowance.

\section{From Collectivism to individualism}

During time, the kibbutz members' sense of identification with the kibbutz and its goals decreased. The second and third generations of kibbutz members were less devoted to the ideals that led kibbutz founders, less ready for self-sacrifice, more pragmatic and more frustrated by the limits of this model: the limited personal property (and the implied financial inability of parents to help grown up children who wanted to leave), the limited options of work, study, career development or chances to experience other forms of self-realization outside the kibbutz, according to the personal interest, rather than serve the interests of the kibbutz. Some envied the relatively few kibbutz members who managed to establish professional careers outside the kibbutz, accumulating power, privileges and prestige. ${ }^{19}$ Others desired a higher standard of living. When the kibbutz 'surrendered' members' pressure, allowing them to have television sets or telephones in their rooms or to travel abroad, their awareness and appetite for 'capitalist' pleasures grew. Questions of personal and group identity and the limits of solidarity were raised.

These doubts were reinforced by a growing conflict between the rural nature of the kibbutzim and the urban pattern of settlement, adopted by most Israelis. This conflict had some dimensions. One aspect was the necessity to subsidize agriculture and provide for a safety net in cases of natural disasters, criticized by urban Israelis, particularly citizens of border towns and development towns, as an unnecessary or rather exaggerated burden on the state's budget. The growing resentment among the Sephardic community in Israel for the kibbutzim, perceived as ivory towers of the Ashkenazi elite, underlined this conflict. ${ }^{20}$

By end 1970's many kibbutzim experienced a severe financial crisis. In 1977 the Likud party was first elected for government, replacing the Avoda party which ruled since the establishment of Israel. While the latter represented left wing, social ideas and was highly supportive of the kibbutzim, the former represented a right-wing, capitalist vision, and was mainly supported by kibbutz opponents, capitalists and urban inhabitants, mostly of Sephardic origin. This government was less attentive to the growing financial needs of the kibbutzim and substantially decreased their financial support. ${ }^{21}$

19 SHAPIRA, R.: Academic Capital or Scientific Progress? A Critique of Studies of Kibbutz Stratification. In: Journal of Anthropological Research, 2005, vol. 61, no. 3, pp. 357-380; SHAPIRA, R.: Communal Decline: The Vanishing of HighMoral Leaders and the Decay of Democratic, High-Trust Kibbutz Cultures. In: Sociological Inquiry, 2001, vol. 71, no. 1, pp. 13-38.

20 In one of his pre-elections speeches, in 1981, Menachem Begin, head of the Likud party, who was elected as Prime Minister in 1977 and served in this office until 1983, incited potential voters from border and development towns against kibbutz members, describing them as millionaires with private swimming pools. A recent research shows that these hard feelings still persist: ASHKENAZI, E.: Mutual Prejudice of Kibbutz Members and Development Towns' Citizens. In: Haaretz, 2007. Available at: http://www.haaretz.co.il/misc/1.1467375

21 NAVON, T.: The Kibbutzim’s Crisis and the Israeli Economic Policy (1977-1989). Haifa: Haifa University, 2010, pp. 1120. Available at: https://observpost.files.wordpress.com/2012/04/d79ed7a9d791d7a8-d794d7a7d799d791d795d7a6d799d79d-d795d794d79ed793d799d7a0d799d795d7aa-d794d79bd79cd79bd79cd799d7aa-d791d799d7a9d7a8.pdf 
At that time, the entire Israeli economy suffered growing financial instability, that gradually developed into stagflation. Many kibbutzim invested their savings in misfortunate financial investments. Other kibbutzim took huge loans from the banks (or in the grey market) to finance both the enlargement of their economic activities, aiming to raise their incomes in the medium and long run, and the immediate desires of their members for a higher standard of living. As inflation augmented to two and then three digits, the kibbutzim could not repay their debts and many of them slid into insolvency. By 1989, strict arrangements were finally worked out, involving the kibbutzim, the banks and the Israeli government, to pull the kibbutzim out of the crisis. Some of the debts were written off, ${ }^{22}$ an act that drew even more resentment to the kibbutzim. Implying substantial lowering of the standard of living, austerity measures taken motivated many kibbutz members, frustrated anyhow due to the reasons mentioned, to leave the kibbutz. In many kibbutzim, the majority of members who chose to stay were the elders. There was insufficient young labour to produce incomes, to finance the growing expenses and pay the debts. The standard of living declined, encouraging more leavings.

This immense crisis forced the kibbutzim's leaders to capitalist thinking, to enable payment of kibbutzim's debts to the banks and restructure their economy: empty houses were rented to nonmembers; services that the kibbutz used to offer for free to its members, such as education, laundry, health and feeding were offered for payment to non-members, to create income and enjoy the economies of scale's advantages, despite the shrinking number of kibbutz members. Gradually, many kibbutzim privatized more and more services, even for their own members, realizing that this move implied a solid income to the kibbutz, and a more economic use of these services by the users. ${ }^{23}$ Many kibbutzim privatized even the ownership of certain properties, such as members' houses and a sort of a 'stock' in the manufacturing component of the kibbutz. Consequently, the kibbutzim became attractive again, both to their original members and to new settlers, some opting for full membership while others opt to live in the kibbutz, enjoying its atmosphere and services for payment, without becoming members.

Despite all these changes, legally until 2005 (to be recognized as [a kibbutz] by the government, it had to be an entity based on collective and equal ownership, as well as on common production, consumption and education). ${ }^{24}$

Nowadays, most of the 270 existing kibbutzim are wholly or mostly privatized, thus considered as 'renewed kibbutzim', perceived by traditional thinkers not to be reflecting the original values of the kibbutz. The kibbutzim continuing under the original kibbutz scheme are associated with the 'collaborative model.'25

Since 2005 the legal definition of the kibbutz recognizes, in addition to the traditional model, the 'renewed kibbutzim', defined as based on shared property, independent labour, equality and sharing of production, consumption and education, and mutual guarantee. The protocol of these kibbutzim has to provide for allocation of the kibbutz's production means (except for land and water), apartments and/or budgets to its members, in proportion to their contribution, position and seniority. ${ }^{26}$

22 Ibid., pp. 46-59.

23 For example, see a description of this process in kibbutz Hulda, in: RIFKIN, L.: Adult Children of the Dream. In: The Jerusalem Post, 2010. Available at: http://www.jpost.com/Jerusalem-Report/Adult-Children-of-the-Dream.

24 Dr. Getz Shlomo, cited ibidem.

25 In 2011 there were 193 'renewed kibbutzim' and 62 'collaborative kibbutzim'. GILBOA, N.: Kibbutzim's Status: 73\% Renewed Kibbutzim, 2011. Available at: http://www.kibbutz.org.il/itonut/2011/dafyarok/110203_mithadshim.htm

26 The full version of the relevant regulation (in Hebrew) is available at: http://www.kibbutz.org.il/tnua/sivug/051218_takanot_sivug.pdf 


\section{THE KIBBUTZ AND THE EU}

\section{Basic Perceptions}

\section{Full integration}

The original kibbutz model was based on 'full integration' of members' powers and property. As this model failed, the majority of kibbutzim backed towards a more flexible model of operation, acceptable by their members, involving a lower level of integration to allow for the continuation of the kibbutz.

While EU leaders encourage quick enhancement towards more intensified integration, ${ }^{27}$ regarding it as inevitable to pull the EU out of current crises, this opinion does not seem to reflect the will of most EU citizens. Similarly to the kibbutz, at least from the political point of view, backing towards a more flexible model of cooperation ${ }^{28}$ may better ensure the continuity of the EU in the long run, whereas insistence on intensifying integration at this point may have an adverse effect.

\section{Equality}

The original kibbutz model was underlined by the notion of its members' equality. Consequently, each member had one voice in the kibbutz's 'general assembly'. Each member was entitled to an equal share of the benefits offered by the kibbutz: food, clothes, housing, education, health etc. Equality was implemented on pragmatic bases, namely: 'from each according to his/her ability, to each according to his/her need.'

In cases where it was impossible to provide a benefit to all interested members simultaneously (e.g. private telephones in the members' rooms, travels abroad, higher education), the kibbutz's authorities decided priorities.

Equality of members is a basic value of the EU as well, ${ }^{29}$ subject to acknowledgment and respect of the differences between the member states and their national contexts. ${ }^{30}$ The application of this value at the EU seems to share many similarities with its application at the kibbutz:

- Each member state has one vote in the highest EU authority, deciding its policy and vision: the European Council, and one Commissioner in the EU Commission. ${ }^{31}$

27 See JUNCKER, J. C.: Completing Europe's Economic and Monetary Union. 2015. Available at http://ec.europa.eu/priorities/economic-monetary-union/docs/5-presidents-report_en.pdf

28 For example, one new flexible model recently discussed by experts and in the press is the creation of a geo-economic German core that would include countries associated with the German supply chain, such as the Netherlands, Poland, the Czech Republic, Slovakia, and certain Scandinavian countries: CARACCIOLO, L. - BRUNELLO, R.: Europe in the Brexit and Trump Era: Disintegration and Regrouping. In: MacroGeo, 2017. Available at: https://www.macrogeo.global/nexus/ europe-in-the-brexit-and-trump-era-dis-integration/. BARBER, T.: Europe Starts to Think the Unthinkable: Breaking Up. In: Financial Times, 2017. Available at: https://www.ft.com/content/0b7b1616-ff3d-11e6-8d8e-a5e3738f9ae4. Five possible scenarios for the potential state of the European Union have been recently presented by the European Commission. White Paper on the Future of Europe, 2017. Available at: http://europa.eu/rapid/press-release_IP-17-385_en.htm

29 See the Preamble and Article 2 of the Treaty on the European Union (TEU), available at: http://eur-lex.europa.eu/LexUriServ/LexUriServ.do?uri=OJ:C:2008:115:0013:0045:en:PDF

30 Article 4 (2) TEU.

31 The sophistication and largeness of the EU system dictates that in other institutions material equality would be obtained by other formulae, by which voting power reflects the number of each member's citizens (e.g. Council of the EU, EU Parliament), or the size of its economy (e.g. the rotation system at the ECB's Governing Council). 
- The contribution of each member state to EU's budget is determined by its GDP ('from each according to its ability').

- Financial (and other) assistance to the member states is decided according to their needs. Consequently, weak economies, or economies suffering a temporary crisis, may enjoy more EU financing than strong economies ('to each according to its need'). ${ }^{32}$

- Priorities, where necessary, are determined by relevant EU authorities.

\section{Formal versus Material Equality}

The kibbutz paid tribute to formal equality. However, many members were frustrated, feeling that in fact they had no influence over decision making, despite their equal right to vote, either because of their non-influential personality, because they identified with a minority opinion or because of their belonging to a group with a relatively low social status in the kibbutz. ${ }^{33}$

In the EU, certain - mainly relatively weak or small member states - feel frustrated that despite their allegedly equal status, strong countries like France and Germany practically dictate priorities. Recently, this frustration is particularly associated with regard to the financial crisis. ${ }^{34}$

\section{Solidarity}

Solidarity is defined as 'unity or agreement of feeling or action, especially among individuals with a common interest; mutual support within a group. ${ }^{35}$ The kibbutz - and the $\mathrm{EU}^{36}$ - are underlined by both these dimensions of solidarity: their members created them out of unity of feeling, values and action, being ready to provide mutual economic, political and defense support within the group. During their history, both these alliances provided the promised mutual guarantee to their members. The kibbutz offered weak members, sick members, old members, disabled members, or members suffering personal crises economic and social support. The EU offers its members political support in external relations, economic support, e.g. through the Common Agricultural Policy (CAP), ${ }^{37}$ cohesion funds, facilities such as the European Stability Mechanism (ESM) developed to pull member states out of the financial crisis, etc.

\section{Abuse of Equality and Solidarity by Free riders}

In the kibbutz, a major source of frustration was the abuse of equality and solidarity by 'free rider' members, who enjoyed all the benefits offered by the kibbutz for minimum labour contribution un-

32 See, for example, PING CHAN, S.: EU Budget: What You Need to Know. In: The Telegraph, 2017. Available at: http:// www.telegraph.co.uk/finance/financialcrisis/11221427/EU-budget-what-you-need-to-know.html

33 One such group included women, who felt that they were expected to function mainly as service providers in fields such as education, laundry and cooking, while men as a group were offered more challenging jobs: LIEBLICH, A. Kibbutz Makom. Jerusalem and Tel Aviv. New York: Shocken, 1986, pp. 105, 112, 205, 264.

34 See, for example: MUNIN, N.: The 'Five Presidents Report': Dogs Bark but the Caravan Moves on? In: European Politics and the Society, 2016, vol. 17, no. 3, pp. 401-420, 404, 415; MUNIN, N.: European Monetary Union's Single Banking Supervision Mechanism: Another Brick in the Wall? In: IUP Journal of International Relations, 2016, vol. X, no. 4, pp. 7-31, 14; MUNIN, N.: Democracy and Financial Crisis Between the Five Presidents Report and the Brexit: In Search for a New Way? In: International and Comparative Law Review, 2016, vol. 16, no. 2, pp. 7-28.

35 Oxford Dictionary. Available at: https://en.oxforddictionaries.com/definition/solidarity.

36 See TEU the Preamble, Article 2, 3, 31, 32; Treaty on the functioning of the EU (TFEU) Articles 67, 80, 122, 194, 222, first paragraph of Protocol no. 28 on economic, social and territorial cohesion. Available at: http://eur-lex.europa.eu/legal-content/ $\mathrm{EN} / \mathrm{TXT} /$ ?uri=celex$\% 3 \mathrm{~A} 12012 \mathrm{E} \% 2 \mathrm{FTXT}$

37 RAMIRO TROITINO, D. - CHOCHIA, A.: The Common Agricultural Policy, its Role in European Integration and Influence on the Enlargements of the Organization. In: International and Comparative Law Review, 2013, vol. 13, no. 1, pp. 39-60. 
justified on grounds of real inability, or abused the common property. ${ }^{38}$ Due to the original kibbutz rules such members, considered 'parasites', could not be expelled from the kibbutz.

In the context of the current financial crisis, similar claims were invoked towards certain assisted countries by frustrated citizens and politicians of the assisting countries. These assisted countries were blamed, among other things, for conducting irresponsible spending policies, for maintaining a huge and inefficient public sector or corrupted governments and for not striving hard enough to raise productivity ${ }^{39}$ Accusers were frustrated that according to EU law, these reasons did not suffice to expel a member state from the Union, and that allegedly they had to bear the costs of this behaviour. ${ }^{40}$

In the kibbutz, privatization of work solved the problem of parasites: everyone is now paid for their actual contribution, and may be fired if they do not perform satisfactorily. They can only enjoy services they can afford paying for. ${ }^{41}$

In the EU, questions such as: to what extent strong members have a moral obligation to support weak (or 'parasite') members? How to treat members acting irresponsibly, thus endangering the entire alliance?, still remain open. In the meantime, solidarity prevailed, associated with the requirement that assisted countries adopt stricter discipline and recovering measures.

Yet another controversy among EU member states refers to the treatment of current huge waves of refugees flooding Europe. To a certain extent, member states refusing to participate in this effort are perceived as 'parasites' by other member states, bearing this entire economic and social burden.

The UK is the second net contributor to EU budget. ${ }^{42}$ The Brexit implies the end of UK's financial contribution to the assisted countries and to further immigration into the $\mathrm{EU}^{43}$

In both contexts, potentially followed by other member states, initiatives like the Brexit may lead to an equivalent by-product as kibbutz privatization: breaking up solidarity (and the support of alleged 'parasites') by withdrawing the alliance.

\section{Subsidiarity}

The original kibbutz was underlined by subsidiarity: it offered individuals desiring to live in an unwelcoming land mutual economic, social and security guarantee. Being a capital-and-labourintensive project, it could be only obtained collectively.

38 LIEBLICH, A. Kibbutz Makom. Jerusalem and Tel Aviv. New York: Shocken, 1986, pp. 53-4.

39 In extreme cases, this frustration turned into an incitement campaign. See, for example: BICKES, H. - OTTEN, T. WEYMANN, L. C.: The Financial Crisis in the German and English Press: Metaphorical Structures in the Media Coverage on Greece, Spain and Italy. In: Discourse and Society, 2014, vol. 25, no. 4, pp. 424-445.

40 MUNIN, N.: The 'Five Presidents Report': Dogs Bark but the Caravan Moves on? In: European Politics and the Society, 2016, vol. 17, no. 3, p. 404. MUNIN, N.: European Monetary Union's Single Banking Supervision Mechanism: Another Brick in the Wall? In: IUP Journal of International Relations, 2016, vol. X, no. 4, p. 11. See also the counter-arguments made by the assisted countries and scholars specified in these articles.

41 Nowadays, certain kibbutz members perceive other members, fulfilling senior positions in the kibbutz, now involving considerable remuneration, as parasites. See: SHAPIRA, E.: Who is a Parasite? Shavim website, 2010. Available at: http:// www.kibbutz.org.il/shavim/articles/yomyom/100630_e_shapira.htm

42 PING CHAN, S.: EU Budget: What You Need to Know. In: The Telegraph, 2017. Available at: http://www.telegraph.co.uk/ finance/financialcrisis/11221427/EU-budget-what-you-need-to-know.html

43 One third (33\%) of leave voters in the Brexit referendum said the main reason was that leaving 'offered the best chance for the UK to regain control over immigration and its own borders'. How the United Kingdom voted on Thursday... and Why. In: Lord Ashcroft's Polls, 2016. Available at: http://lordashcroftpolls.com/2016/06/how-the-united-kingdom-votedand-why/ 
The notion of subsidiarity underlines the EU as well: ${ }^{44}$ it enabled its members to become the largest trade block in the world, thus to profit from a better bargaining power than each of them would have had individually. It enabled the issuing of a mutual currency: the Euro, the second most attractive investment currency in the world, after the US Dollar. It facilitated the restructuring of Europe after World War II and the obtainment of peace in Europe ever since. It facilitated the stabilization and upgrading of Central and Eastern European economies after their release from communist regime. It facilitates cross-border projects that cannot be pursued by individual member states, in fields such as international transportation and the environment.

With privatization, kibbutzim lost much of the advantages offered by their original model in terms of subsidiarity. They can still perform as a group to obtain mutual external advantages or exercise a collective bargaining power. Nevertheless, the ideological variety and different motivations characterizing the members (and other citizens) of current kibbutzim, the weakening status of the kibbutzim in the Israeli society and the lack of their economic consolidation as a group decrease their subsidiary power to a great extent. This is an interesting point to bear in mind for Eurosceptics.

\section{External Labour}

The original kibbutz model was based solely on internal labour. In ideological terms, this was explained by the communist/socialist perception that hiring other people to work for them would turn kibbutz members into capitalists, exploiting the working class. ${ }^{45}$ As the economic needs of the kibbutzim grew, due to the growth in the number of their members and their growing expectations for a higher standard of leaving, this ideology became more and more controversial. In certain cases, kibbutz members argued that even if all of them worked as hard as they could, it was still impossible to meet all the needs of the kibbutz. This distress grew as the second and third generations of kibbutz members had to support a constantly growing group of retired elders, a challenge that the kibbutz founders did not face. In other cases, frustration emanated from the necessity to perform jobs that no kibbutz member fancied. Kibbutz leaders forced members to perform them using a mix of carrots and sticks. Yet a third justification to hire external workers occurred where the kibbutz needed a professional service that no member could provide, e.g. physicians, social workers or other experts. ${ }^{46}$ During the years, as the ideological foundations of the kibbutz became shaky and the needs grew, more and more kibbutzim surrendered to members' pressure to some extent. ${ }^{47}$ In the 1970s kibbutzim frequently hired Arab labourers. Due to the political escalation and growing threat of terror, since the 1990s local Arab workers were replaced by teams of foreign workers, many from Thailand and China.

The growing share of elder population in the entire population, combined with the average low birth ratio, the preference of EU citizens not to perform certain, particularly labour-intensive jobs and the necessity for external experts in certain cases led the EU to a similar dilemma. ${ }^{48}$ Nevertheless, while the kibbutz could afford abstaining from turning most of external workers into kibbutz members, in the EU's reality this is more difficult. Experts, for example, can stay at the EU for short

44 Article 5 TEU, Article 3 TFEU, Protocol (No. 2) on the principles of subsidiarity and proportionality.

45 LIEBLICH, A. Kibbutz Makom. Jerusalem and Tel Aviv. New York: Shocken, 1986, pp. 35, 37, 106-7, $131,200$.

46 Ibid., pp. 260.

47 See, for example, INBARI, A.: Habayta. Tel Aviv: Yediot Sfarim, 2009.

48 Eurostat. Europe 2020 Indicators - Employment. 2016. Available at: http://ec.europa.eu/eurostat/statistics-explained/ index.php/Europe_2020_indicators_-_employment 
intervals. In border areas, workers can cross the border daily to work in the EU and return to their homes, outside the EU, after work. But most of the foreign workers immigrate to the EU, in many cases with their families. This reality imposes EU leaders and citizens to the dilemma: how to deal with social side-effects of foreign labour's employment? To what extent do foreign workers affect the homogeneity of the local/national/EU social tissue? To what extent social homogeneity is important to the success of the alliance?

Labour immigration in the EU encompasses internal immigration, i.e. between member states, and external immigration, i.e. from third countries. ${ }^{49}$ While more tolerance could have been anticipated towards the former, unfortunately this is not the case. Some argue that in fact, intensified labour immigration into the UK and the feeling of many UK citizens that their communities were 'captured' by foreign cultures, as well as the feeling that intensive immigration lowers wages and overburdens health and education systems formed major triggers to the Brexit vote. ${ }^{50}$

Foreign immigrants, particularly those of Muslim origin, invoke even stronger resistance, due to more extreme cultural differences, combined with their different religion and their association with a potential security threat, following terrorist incidents associated with extreme Muslim movements, occurring in recent years all over Europe. These fears are further reinforced by the refusal of many of these foreign immigrants to assimilate into the hosting countries' societies by learning their language, adopting their manner of dressing and to a certain extent - their culture. Some even refuse to engage in productive work, taking advantage of social security schemes to support them financially. ${ }^{51}$ Member states refusing to allow the access of immigrants justify this position not only on grounds of potential security threats that such immigration may involve, but also on grounds of the potential damage such immigration implies to their social tissue, referring to the experience of countries such as France, Germany, Belgium and Sweden..$^{52}$

When the state of Israel was established, the kibbutzim participated in the general national efforts to handle the huge waves of Jewish refugees or immigrants who came to Israel. To that extent, the kibbutz offered some schemes:

Short term scheme: in times of Ottoman and British regimes, part of the refugees stayed at the

49 According to Eurostat, foreign citizens made up $7.4 \%$ of persons in employment in the EU in 2015. The split between intra- and extra-EU migrants was almost even, with $3.6 \%$ having their citizenship from another EU country, and $3.8 \%$ coming from outside the EU. Eurostat. Labor Market and Labor Force Survey (LFS) Statistics, 2016. Available at: http:// ec.europa.eu/eurostat/statistics-explained/index.php/Labour_market_and_Labour_force_survey_(LFS)_statistics

50 TILFORD, S.: Britain, Immigration and Brexit. In: CER Bulletin, 2016. Available at: https://www.cer.org.uk/sites/default/ files/bulletin_105_st_article1.pdf See also: The Migration Observatory. Migration and Brexit. 2017. Available at: http:// www.migrationobservatory.ox.ac.uk/projects/migration-and-brexit/

51 YEHEZKELI, Z. - DERYI, D.: Allah Islam - Documentary on the Muslims in Europe. 2012. Available at: https://www. youtube.com/watch?v=hR7REARFFpQ; For more details on the link between unemployment and national social policies in the EU see: HUNGLER, S.: The Poor, The Unemployed and the Public Worker - A Comparative Essay on National Unemployment Policies Contribution to Deepening Poverty. In: International and Comparative Law Review, 2012, vol. 12, no. 1, pp. 123-140.

52 See, for example, MORTIMER, C.: Hungary Set to Reject EU Refugee Quotas in Referendum in Victory for Ruling AntiImmigration Party. In: Independent, 2016. Available at: http://www.independent.co.uk/news/world/europe/hungary-eureferendum-refugee-quota-migrant-crisis-xenophobia-border-control-racism-a7341276.html; FREJ, W.: Here Are the European Countries that Want to Refuse Refugees. In: Worldpost, 2017. Available at: http://www.huffingtonpost.com/ entry/europe-refugees-not-welcome_us_55ef3dabe4b093be51bc8824. A recent poll by the UK's Royal Institute of International Affairs reflects that an average of $55 \%$ across $10 \mathrm{EU}$ member states support stopping Muslim immigration to the EU: GOODWIN, M. - RAINES, T. - CUTTS, D.: What do Europeans Think about Muslim Immigration? In: Chatham House, 2017. Available at: https://www.chathamhouse.org/expert/comment/what-do-europeans-think-about-muslimimmigration 
kibbutzim temporarily, for short periods after their illegal arrival, pretending to be kibbutz members to hide from authorities until a permanent arrangement would have been found for them. In these cases, the kibbutzim did not bear the long term burden of refugees' treatment.

Medium term scheme: Other refugees stayed in the kibbutzim as 'external children', an arrangement that was meant to provide a home for children who immigrated without their families (particularly after World War II), until they have reached the age of eighteen. Thereafter, their potential long term kibbutz membership was mutually considered, according to their individual circumstances and desires.

Long term scheme: Certain refugees aimed immediately upon arrival at becoming full members. In addition, after Israel's establishment, immigrants joined kibbutzim as individuals, out of their own considerations.

In all cases, immigrants were expected to contribute to the overall labour effort from day one. Except for the short term scheme (that may be seen as equivalent to temporary stay of immigrants in EU countries, crossed on the way to the final destination) they were expected to learn Hebrew and to assimilate culturally and socially as soon as possible. In the long run, this approach ensured a process of natural filtering of the individuals who could not meet this challenge, and the maintenance of the unique character and social tissue of the kibbutz.

Moreover, in most cases the kibbutz made sure that an immigrant would become a full kibbutz member (with voting rights) only after a long process of assimilation. Any such membership application had to be decided in the 'general assembly', after the majority of kibbutz members were satisfied that the candidate performs satisfactorily both in social terms and in terms of labour. ${ }^{53}$

By analogy, the EU might have profited from applying a similar, stricter policy towards immigrants desiring to stay in EU member states as residents or citizens.

In the 1970's, due to a growing national criticism on the kibbutz for not contributing enough to the national effort of assimilating immigrants into the Israeli society during the 1950 's, ${ }^{54}$ some of the kibbutzim sent their youth to work outside the kibbutz, as social guides of street gangs and population of low socio-economic status in development towns, consisting mainly of former immigrants. This project offered an opportunity for mutual cultural acquaintance and contributed to some gap-bridging and resentment reduction between these groups. ${ }^{55}$ A similar approach could have enhanced social consolidation in the EU.

Massive immigration invokes the question whether, and to what extent, religious and cultural homogeneity is essential to the success of a collective such as the kibbutz or the EU.

Historically, the majority of kibbutz founders were Ashkenazi Jews. Jewish individuals of Sephardic origin found it difficult to assimilate in this society, that did not welcome them. ${ }^{56}$ During the years, cultural awareness in the kibbutzim (and in Israel as a whole) grew, reinforced by mixed marriages that produced offsprings of mixed origins. The reality of the Israeli society as a melting

53 LIEBLICH, A. Kibbutz Makom. Jerusalem and Tel Aviv. New York: Shocken, 1986, pp. 54-65, 69-72, $216-230$.

54 In the 1950's huge immigration waves included many elders, families, sick and wounded newcomers. Most of them did not settle in the kibbutzim. The kibbutzim were blamed for deliberately refraining to assimilate them. Consequently, the national image and status of the kibbutzim dropped. Such newcomers who desired agricultural life preferred the Moshavim, agricultural settlements where families form independent economic units. Many others settled in development or border towns.

55 LIEBLICH, A. Kibbutz Makom. Jerusalem and Tel Aviv. New York: Shocken, 1986, p. 316.

56 Ibid., pp. 59-65, 69-72. 
pot further blurred these differences, so that nowadays this issue seems to be of less interest and importance, albeit the image of kibbutz is still broadly associated with Ashkenazim.

Moreover, following some appeals by Israeli citizens of Arab origin to the Israeli Court of Justice, arguing that their requests to become kibbutz or community town members were refused on grounds of their origin, the court provided that such practices are unconstitutional, rejecting claims that such practices would substantially change the unique, homogeneous social tissue of the settlement at stake. ${ }^{57}$ These decisions opened the way to Arab membership in the kibbutzim, although in the meantime such practice is very rare.

The EU is mainly a Christian society. ${ }^{58}$ Some argue that part of its identity is based on the exclusion and fear of the Other..$^{59}$ Although the TFEU provides for non-discrimination, among other things on grounds of religion, ${ }^{60}$ deterrence from a substantial change of its generally homogeneous social tissue seems to be, for example, one of the motives for EU's ongoing avoidance to accept Turkey, a huge Muslim country, as a member state, as well as for the recent broad outcry against the huge waves of Muslim refugees, added to the large Muslim population already living in the EU.

Despite the shared, desired image of cultural melting-pots, it seems that both the kibbutz and the EU find it difficult to live by this image or goal.

\section{RECENT EU DILEMMAS AND THEIR PARALLEL IN THE HISTORY OF THE KIBBUTZ}

\section{Little and selective or big and less selective alliances?}

The first kibbutzim were very small and intimate, encompassing only a few members. This framework had some advantages: the group could have been selective; to a great extent, the group was culturally and religiously homogeneous; all group members shared similar ideas and were devoted to their fulfilment. They were established by young and elitist members of European origin. On the other hand, this format had many disadvantages: the small groups were poor and could not handle large scale projects that would have yielded more income. They could barely handle daily security threats and the hard terms of living. Consequently, they strove to enlarge the kibbutzim.

Kibbutzim grew to include hundreds of members. In many cases, some were strangers to others. Aside advantages such as economies of scale, this reality implied disadvantages such as less selectivity, that could adversely affect the personal quality of the members, in some cases encouraging a lower sense of members' responsibility. The 'general assembly' - superior decision making forum of the kibbutz, where all members had speaking and voting rights, became greatly ineffective. Moreover, this relatively huge format consumed a great administrative effort. ${ }^{61}$

The EU started its way with six member states, gradually growing to 28 members. While the founding members were relatively economically strong, many members that joined later were eco-

\footnotetext{
57 E.g. HCJ 8036/07 Fatina Ebriq Zubeidat et al. v. The Israel Land Administration, et al (re community town Rakefet); HCJ 6698/95 Aadel Ka'adan, et al. v. The Israel Land Administration, et al. (re community town Katzir).

58 WEILER, J.: L’Europe Chrétienne: une Excursion. Paris: Éditions du Cerf, 2007.

59 KONOPACKI, S.: Europe and its Problem with Identity in the Globalized World. In: European Studies, 2014, vol. 1, pp. 56-69.

60 Articles 10, 19, TFEU.

61 LIEBLICH, A. Kibbutz Makom. Jerusalem and Tel Aviv. New York: Shocken, 1986, pp. 32, 183-214.
} 
nomically weaker, necessitating financial assistance. Members previously under communist regime further needed support in establishing market economies as well as features that would turn them into solid democracies, e.g. the rule of law, anti-corruption systems, and strong enforcement mechanisms. While this large alliance offers advantages such as economies of scale and political stability, the different economic and political profile of the different EU member states forms a source of constant challenges and disagreements. ${ }^{62}$ Similarly to the kibbutz, decision making processes in the EU became more elaborated and less efficient, despite the adaptations made by the Treaties, and handling this huge framework necessitates a great administrative effort. In December 2016, a report by Guy Verhofstadt, suggesting a substantial reform in the roles of major EU institutions in the decision-making process, was approved in the EU Parliament's AFCO Committee by a large majority. ${ }^{63}$

\section{Conflicts of powers}

In the EU, there is a constant conflict of power between the supranational and national regimes, underlying the 'democratic deficit' frustration. While EU authorities seem to aim at enhancing market integration, towards a federation, ${ }^{64}$ the national regimes, acting under the pressure of their voters, try to maintain their powers to the extent possible. ${ }^{65}$ This conflict fills a decisive role in the current political crisis that evolved on grounds of what is perceived by many EU citizens as unacceptable dictations by EU authorities regarding the solutions to the current financial, political and refugees' crises.

When the state of Israel was established, the kibbutzim, that already existed and were used to a relatively high level of independence, were frustrated by the acts of David Ben Gurion, the first Israeli prime-minister, who tried to impose the power of the state on them, to prevent anarchy. Ben Gurion dismantled the Palmach (defense forces established by the kibbutzim before the state of Israel was established), replacing it by the IDF, managed by the government, and transferred all the powers to prepare Jewish youth abroad for immigration to Israel and kibbutz life from the kibbutzim to the new government. Many kibbutz members experienced these attempts as a conflict of powers, refusing to obey. However, they mainly resisted the timing of establishing the Jewish state, which they considered to be too early, not the very necessity for a Jewish state as a final goal. Thus, it did not take Ben Gurion a long time to bring all the kibbutzim under the umbrella of the new state: as the new state found itself immediately after its formal establishment under an existential military threat, everybody realized that the chances to maintain the state depend upon unifying forces to meet immediate challenges. ${ }^{66}$

62 Which appears regularly and orbits mainly around the topical questions of sovereignty and division of powers, like in the current dispute on so called OMT programme, see HAMULÁK, O. - KOPAL, D. - KERIKMÄE, T.: Walking a Tightrope - Looking Back on Risky Position of German Federal Constitutional Court in OMT Preliminary Question. In: European Studies: the review of European law, economics and politics, 2016, vol. 3, pp. 115-141; or in general to the issue of sovereignty HAMULÁK, O.: Lessons from the "Constitutional Mythology" or How to Reconcile the Concept of State Sovereignty with European Integration. In: Danube: Law and Economics Review, 2015, vol. 6, no. 2, pp. 75-90.

63 ALDE. before: Today, Guy Verhofstadt's report on the reform of the European Union has been approved in the European Parliament's AFCO committee by a large majority. 2016. Available at: http://alde.eu/en/news/782-today-guy-verhofstadts-report-on-the-reform-of-the-european-union-has-been-approved-in-the-european-parliament-s-afco-committeeby-a-large-majority/

64 JUNCKER, J. C.: Completing Europe's Economic and Monetary Union. 2015. Available at http://ec.europa.eu/priorities/ economic-monetary-union/docs/5-presidents-report_en.pdf

65 For discussion on major theories trying to analyse the relationships between national and supranational regime at the EU see: KOPAL, D.: Is Constitutional Pluralism Really Pluralist? In: European Studies, 2015, vol.2, pp. 186-196.

66 LIEBLICH, A. Kibbutz Makom. Jerusalem and Tel Aviv. New York: Shocken, 1986, pp. 128. Kibbutz members objecting the timing of Israel's establishment believed that without the formality of a state it would have been easier to continue the 
The case of the EU is more elaborated in this sense, since there does not seem to be a broad consensus over the final goal of this alliance. Moreover, at this stage even the level of integration already obtained seems to be doubted by certain member states, considering to withdraw it wholly or partly. This reality inflames the conflict of powers. To solve it, broad decision on the final destination of this alliance should be obtained. It seems that the current threats the EU faces are insufficient to trigger such unification of forces.

\section{Citizens' passivity leads to detachment and indifference}

The kibbutz founders were both ideologically and pragmatically active, fuelled by the challenge of creating a globally new form of community, as well as by the daily economic, social and security challenges. They succeeded to transfer part of this enthusiasm and commitment to the kibbutz project to the second generation, mainly through education. However, by the time the third generation turned adolescents, these strong feelings of ideological and pragmatic enthusiasm were watered down by the experience of growing in a strong, smoothly managed system that seemed to function perfectly. This generation felt that everything is ready, in some cases taking the kibbutz reality for granted, thinking that there is nothing more to change or improve and thus - there is no challenge, no opportunity for trial and error, no meaning. The sense that the functioning of the kibbutz is indifferent to whatever they choose to do or not do led to passivity of the young generation, followed by their deep frustration and lack of clear personal direction. ${ }^{67}$ In the long term, these counterproductive feelings, encouraging kibbutz members to avoid responsibility, weakened the kibbutz, harming its daily functioning. When the crises hit many of these passive members were unwilling to stay and struggle for kibbutz recovery.

In the EU, equivalent frustration, emanating from a lack of clear vision about the desired EU future, shared by many of its citizens, combined with the sense of 'democratic deficit' and detachment from decision-making processes, leads many citizens to an equivalent passivity, fuelled by frustration. The misfortunate results of this passivity have been recently reflected by the poor economic situation of certain members. They were further reflected by the default of many young UK citizens to exercise their voting rights in the Brexit referendum, that could have changed the referendum's results, dominated by a great percentage of elder voters. ${ }^{68}$

\section{Regulation}

The original kibbutz was underlined by full commitment of its members to this framework. The second and third generations, who were less devoted to the ideology and more pragmatic, gradually started to deviate from the underlining principles of the kibbutz. To stop this erosion, the kibbutz drafted more and more regulations that the members were required to follow. ${ }^{69}$

The EU is a legal entity, underlined by regulation. However, irresponsible behaviour of member

'settlement enterprise' in Israel, while its establishment may imply freezing of its size BAR ON, M. - MELTZER, A.: The Kibbutz. Documentary (4 chapters), 2013, chapter 3. Available at: https://www.youtube.com/watch?v=pVbgxd7Z3mQ

68 LIEBLICH, A. Kibbutz Makom. Jerusalem and Tel Aviv. New York: Shocken, 1986, pp. 294, 301, 303, $314,317$.

68 While elders' turnout was $90 \%$, youngsters' (18-24) turnout was only $36 \%$. It was assessed that the majority of youngsters would have supported remaining in the EU. See, for example: SPEED B.: How Did Different Demographic Groups Vote in the Referendum? In: The Staggers, 2016. Available at: http://www.newstatesman.com/politics/staggers/2016/06/howdid-different-demographic-groups-vote-eu-referendum

69 BAR ON, M. - MELTZER, A.: The Kibbutz. Documentary (4 chapters), 2013, chapter 3. Available at: https://www.youtube.com/watch?v=pVbgxd7Z3mQ 
states, such as ignoring the financial stability criteria known as the 'Maastricht Criteria' before the financial crisis, encouraged more detailed regulation, to impose stricter discipline.

In both cases, individual members find it hard to follow the constantly developing regulation and live by it. In both cases, regulation is necessary, but at the same time forms a constant source of frustration and its enactment - and enforcement - consume a great time and administrative effort. In both cases, over-regulation seems to obtain the opposite effect.

\section{Handling of the financial crisis}

Both in the kibbutz and in the EU, the financial crisis was a result of a combination of unforeseen, misfortunate external circumstances with poor, or even irresponsible, leaders' decisions. In both cases, some kibbutzim and EU member states were adversely affected more than others. In both cases, intervention by external authorities was necessary to solve the crisis: in the case of the kibbutzim it was the Israeli government. In the case of the EU - EU authorities intervened, with the help of international institutions such as the IMF and the World Bank. In both cases, the adversely affected kibbutzim/member states suffered severe austerity and were forced to engage in far-reaching reforms to recover their economies. In both cases, some of the debts were written off while others were spread into bearable payments.

Eventually, most of the kibbutzim recovered the crisis. Success of recovery programs depended, to a great extent, on their willingness to take determinant action to change their old, mal-functioning model. In many kibbutzim, a certain level of privatization was necessary to that extent. This practice may be advisable for - and is already followed by - some EU member states, suffering an excessively large and inefficient public sector. The kibbutzim imposed responsibility on their members, shifting their regime to include authoritative management and differential wages. In certain kibbutzim, giving up old, unprofitable production sectors in favour of new, yielding sectors, was necessary. Thus, for example, ZAP, an Israeli successful website comparing prices, was established by a partnership between a kibbutz member and his kibbutz (Ramat Hakovesh).$^{70}$ Kibbutz Eyal in the Sharon, in the centre of Israel, developed Eyal Microwave company, making a nice exit by selling it to the American Hereley Industries in $2008 .{ }^{71}$ Creative thinking helped certain kibbutzim to turn economic disadvantages into advantages. Thus, for example, finding themselves mainly with elder members, as the majority of young kibbutz members left, in desperate need for income to support these members, who were in retirement age, two kibbutzim: Degania Aleph and Beth, both originating from the first Israeli kibbutz: Degania now offer paid services of elders' care to external consumers. Kibbutz Saar, in the Galilee, rented its old, no more used, dining room to a hi-tech company, using it as its main office. It aims to attract more hi-tech companies, to become a regional hi-tech centre, hoping that some of the hi-tech companies' employees may consider becoming kibbutz members. ${ }^{72}$ Charging kibbutz members for particular goods and services raised their awareness to the costs of these services, encouraging more economic consumption. The shift to paid work strengthened the necessary link between financial capability and consumption, encouraging more responsible economic behaviour.

Similar strategies, adapted to their reality, may be helpful to pull EU member states out of the financial crisis. Many of them are already implemented by these states and EU authorities, e.g.

0 www.zap.co.il

71 GRIMLAND, G.: Kibbutz Eyal's Exit. In: TheMarker, 2008. Available at: http://www.themarker.com/technation/1.1757816

72 MELTZ, J.: The New Trend: Start-ups in the Kibbutzim. In: Globes, 2002. Available at: http://www.globes.co.il/news/ article.aspx? $\mathrm{did}=609054$ 
under Europe 2020 strategy, aiming at the development of an economy based on knowledge and innovation ('smart growth'), which is more efficient, greener and more competitive ('sustainable growth'), a high-employment economy delivering economic, social and territorial cohesion ('inclusive growth') and national recovery programs. ${ }^{73}$

\section{CONCLUSION}

Despite the substantive differences between the Israeli kibbutz and the EU, both seem to share similar characteristics, perceptions, and dilemmas.

Comparison of these two attempts to build a model based on total collectivism seems to illustrate that despite theoretical advantages, such total models do not correspond to the human, individualist nature and to some extent are thus counter-productive, discouraging individual sense of responsibility and creativity. However, strong belief, persistent approach and creative thinking may produce more flexible models, encompassing a broadly agreed compromise between collectivism and individualism that would successfully function, to the benefit of its members.

\section{Bibliography:}

ASHKENAZI, E.: Mutual Prejudice of Kibbutz Members and Development Towns' Citizens. In: Haaretz, 2007. Available at: http://www.haaretz.co.il/misc/1.1467375

BAR ON, M. - MELTZER, A.: The Kibbutz. Documentary (4 chapters), 2013, chapter 3. Available at: https://www. youtube.com/watch?v=pVbgxd7Z3mQ

BARBER, T.: Europe Starts to Think the Unthinkable: Breaking Up. In: Financial Times, 2017. Available at: https:// www.ft.com/content/0b7b1616-ff3d-11e6-8d8e-a5e3738f9ae4

BETTELHEIM, B.: The Children of the Dream. New York: Simon \& Schuster, 2001.

BICKES, H. - OTTEN, T. - WEYMANN, L. C.: The Financial Crisis in the German and English Press: Metaphorical Structures in the Media Coverage on Greece, Spain and Italy. In: Discourse and Society, 2014, vol. 25, no. 4, pp. $424-445$.

BOSSO, N.: When Farmers Found Gold in the Land. In: TheMarker, 2014. Available at: http://www.themarker.com/ magazine/1.2456648

CARACCIOLO, L. - BRUNELLO, R.: Europe in the Brexit and Trump Era: Disintegration and Regrouping. In: MacroGeo, 2017. Available at: https://www.macrogeo.global/nexus/europe-in-the-brexit-and-trump-era-dis-integration/

Degania Group. Available at: www.Degania.org.il

Eurostat. Europe 2020 Indicators - Employment. 2016. Available at: http://ec.europa.eu/eurostat/statistics-explained/ index.php/Europe_2020_indicators_-_employment

Eurostat. Labor Market and Labor Force Survey (LFS) Statistics, 2016. Available at: http://ec.europa.eu/eurostat/ statistics-explained/index.php/Labour_market_and_Labour_force_survey_(LFS)_statistics

FREJ, W: Here Are the European Countries that Want to Refuse Refugees. In: Worldpost, 2017. Available at: http:// www.huffingtonpost.com/entry/europe-refugees-not-welcome_us_55ef3dabe4b093be51bc8824

GILBOA, N.: Kibbutzim’s Status: 73\% Renewed Kibbutzim, 2011. Available at: http://www.kibbutz.org.il/itonut/2011/ dafyarok/110203_mithadshim.htm

73 PORTO, M.: The Path Towards European Integration: the Challenge of Globalization. In: European Studies, 2014, vol. 1 , pp. 41-55. 
GOLDENBERG, S. - WEKERLE, G.: From utopia to total institution in a single generation: the kibbutz and Bruderhof. In: International Review of Modern Sociology, 1972, vol. 2, no. 2, pp. 224-232.

GOODWIN, M. - RAINES, T. - CUTTS, D.: What do Europeans Think about Muslim Immigration? In: Chatham House, 2017. Available at: https://www.chathamhouse.org/expert/comment/what-do-europeans-think-aboutmuslim-immigration

GRIMLAND, G.: Kibbutz Eyal's Exit. In: TheMarker, 2008. Available at: http://www.themarker.com/technation/1.1757816

HAMULÁK, O. - KOPAL, D. - KERIKMÄE, T.: Walking a Tightrope - Looking Back on Risky Position of German Federal Constitutional Court in OMT Preliminary Question. In: European Studies: the review of European law, economics and politics, 2016, vol. 3, pp. 115-141.

HAMULÁK, O.: Lessons from the "Constitutional Mythology" or How to Reconcile the Concept of State Sovereignty with European Integration. In: Danube: Law and Economics Review, 2015, vol. 6, no. 2, pp. 75-90.

How the United Kingdom voted on Thursday....and Why. In: Lord Ashcroft's Polls, 2016. Available at: http://lordashcroftpolls.com/2016/06/how-the-united-kingdom-voted-and-why/

HUNGLER, S.: The Poor, The Unemployed and the Public Worker - A Comparative Essay on National Unemployment Policies Contribution to Deepening Poverty. In: International and Comparative Law Review, 2012, vol. 12, no. 1, pp. 123-140

INBARI, A.: Habayta. Tel Aviv: Yediot Sfarim, 2009.

JUNCKER, J. C.: Completing Europe’s Economic and Monetary Union. 2015. Available at http://ec.europa.eu/priorities/economic-monetary-union/docs/5-presidents-report_en.pdf

KONOPACKI, S.: Europe and its Problem with Identity in the Globalized World. In: European Studies, 2014, vol. 1, pp. 56-69.

KOPAL, D.: Is Constitutional Pluralism Really Pluralist? In: European Studies, 2015, vol.2, pp. 186-196.

LIEBLICH, A.:Kibbutz Makom. Jerusalem and Tel Aviv. New York: Shocken, 1986.

MELTZ, J.: The New Trend: Start-ups in the Kibbutzim. In: Globes, 2002. Available at: http://www.globes.co.il/news/ article.aspx? $\mathrm{did}=609054$

MORTIMER, C.: Hungary Set to Reject EU Refugee Quotas in Referendum in Victory for Ruling Anti-Immigration Party. In: Independent, 2016. Available at: http://www.independent.co.uk/news/world/europe/hungary-eu-referendum-refugee-quota-migrant-crisis-xenophobia-border-control-racism-a7341276.html

MUNIN, N.: Democracy and Financial Crisis Between the Five Presidents Report and the Brexit: In Search for a New Way? In: International and Comparative Law Review, 2016, vol. 16, no. 2, pp. 7-28.

MUNIN, N.: European Monetary Union's Single Banking Supervision Mechanism: Another Brick in the Wall? In: IUP Journal of International Relations, 2016, vol. X, no. 4, pp. 7-31.

MUNIN, N.: The 'Five Presidents Report': Dogs Bark but the Caravan Moves on? In: European Politics and the Society, 2016, vol. 17, no. 3, pp. 401-420.

NAVON, T.: The Kibbutzim's Crisis and the Israeli Economic Policy (1977-1989). Haifa: Haifa University, 2010, pp. 11-20. Available at: https://observpost.files.wordpress.com/2012/04/d79ed7a9d791d7a8-d794d7a7d799d791d795d7a6d799d79d-d795d794d79ed793d799d7a0d799d795d7aa-d794d79bd79cd79bd79cd799d7aa-d791d799d7a9d7a8.pdf

Oxford Dictionary. Available at: https://en.oxforddictionaries.com/definition/solidarity

PING CHAN, S.: EU Budget: What You Need to Know. In: The Telegraph, 2017. Available at: http://www.telegraph. co.uk/finance/financialcrisis/11221427/EU-budget-what-you-need-to-know.html

PORTO, M.: The Path Towards European Integration: the Challenge of Globalization. In: European Studies, 2014, vol. 1, pp. 41-55.

RAMIRO TROITINO, D. - CHOCHIA, A.: The Common Agricultural Policy, its Role in European Integration and Influence on the Enlargements of the Organization. In: International and Comparative Law Review, 2013, vol. 13, no. 1, pp. 39-60. 
RIFKIN, L.: Adult Children of the Dream. In: The Jerusalem Post, 2010. Available at: http://www.jpost.com/Jerusalem-Report/Adult-Children-of-the-Dream

SHAPIRA, E.: Who is a Parasite? Shavim website, 2010. Available at: http://www.kibbutz.org.il/shavim/articles/ yomyom/100630_e_shapira.htm

SHAPIRA, R.: Academic Capital or Scientific Progress? A Critique of Studies of Kibbutz Stratification. In: Journal of Anthropological Research, 2005, vol. 61, no. 3, pp. 357-380.

SHAPIRA, R.: Communal Decline: The Vanishing of High-Moral Leaders and the Decay of Democratic, High-Trust Kibbutz Cultures. In: Sociological Inquiry, 2001, vol. 71, no. 1, pp. 13-38.

SPEED B.: How Did Different Demographic Groups Vote in the Referendum? In: The Staggers, 2016. Available at: http://www.newstatesman.com/politics/staggers/2016/06/how-did-different-demographic-groups-vote-eureferendum

STERNHELL, Z.: The Founding Myths of Israel: Nationalism, Socialism and the Making of the Jewish State. Princeton: Princeton University Press, 1998.

The Israeli Central Bureau of Statistics, 2017 Population. Available at: http://www.cbs.gov.il/publications17/yarhon0117/pdf/b1.pdf

The Israeli Central Bureau of Statstics. The Kibbutzim and Their Population: Demographic Changes During the Years 1961-2005, 2008. Available at: http://www.cbs.gov.il/publications/kib05/pdf/h_print.pdf

The Migration Observatory. Migration and Brexit. 2017. Available at: http://www.migrationobservatory.ox.ac.uk/ projects/migration-and-brexit/

TILFORD, S.: Britain, Immigration and Brexit. In: CER Bulletin, 2016. Available at: https://www.cer.org.uk/sites/ default/files/bulletin_105_st_article1.pdf

WEILER, J.: L'Europe Chrétienne: une Excursion. Paris: Éditions du Cerf, 2007.

White Paper on the Future of Europe, 2017. Available at: http://europa.eu/rapid/press-release_IP-17-385_en.htm www.zap.co.il

YEHEZKELI, Z. - DERYI, D.: Allah Islam - Documentary on the Muslims in Europe. 2012. Available at: https://www. youtube.com/watch?v=hR7REARFFpQ

ZURIEL HARARI, K.: The Basketball Player, the Lebanese and Kibbutz Elders: Behind the Huge Exit of Hanita. In: Calcalist, 2017. Available at: http://www.calcalist.co.il/local/articles/0,7340,L-3706492,00.html

\section{Contact information:}

Prof. Nellie Munin LLD

Advocate

https://www.nelmun.com/ 